\title{
写真地図作成における逆投影法を用いた数値標高モデルの高精度化
}

\section{Improvement in the Accuracy of DEM for Orthophoto Generation by Reverse Projection Method}

\author{
杉山 史典*・近津 博文** \\ Fuminori SUGIYAMA and Hirofumi CHIKATSU
}

\begin{abstract}
Recently, generation of the orthophoto using digital aerial photograph is performed for the maintenance of spatial information data for wide areas by middle scale. For orthophoto generation, digital elevation model (DEM) by the stereo matching methods is widely used. For the efficiency of orthophoto generation, mismatching should be removed and accuracy should be improved effectively in stereo matching process.

With this motive, new method which is called "Reverse-Projection Method" to remove mismatching points on DEM generation is proposed. The most remarkable points of the method are its ability to detect mismatching points and improve accuracy of DEM using only neighbor stereo models on the strip or the next strip, and the effectiveness of the method is discussed in this paper.
\end{abstract}

\section{1.はじめに}

2007年 5 月に成立した「地理空間情報活用推進基本 法」を受けて地理空間情報の活用施策が推進され，縮 尺 $1 / 2,500$ から $1 / 5,000$ 縮尺かつ, 広範囲にわた る空間データの整備が進められている。この空間デー 夕は国土の基盤情報として使用されるため，位置精度 が要求されるばかりでなく, デー夕の鮮度も要求され ており，少なくとも数年に一度の頻度で更新されなけ ればならないものである。このような空間デー夕整備 の一環として，デジタル空中写真画像を使用した写真 地図作成が行われている。

写真地困は航空写真測量の生成物である数值標高モ デルを用いて空中写真画像を正射変換することによっ て作成されるが，ミスマッチングにより数值標高モデ ルの高さ情報が正しく取得されていない箇所では，写 真地図画像の歪み，画像をモザイク処理する際の接合 ズレ，および既存の地図データとの位置不整合が発生 するため，目視による点検および修正が必要となる。

\footnotetext{
* 朝日航洋株式会社

**東京電機大学理工学部理工学科建築・都市環境学系

「写真測量とリモートセンシング」VOL. 50，NO. 2， 2011

したがって, 写真地図作成の効率化は数值標高モデル 作成におけるミスマッチングの防止に集約される。

ミスマッチングを防止するための取り組みとして, 空中写真画像をエピポーララインと平行な方向に偏歪 修正処理した画像（以下，エピポーラ画像）を作成し て探索範囲を制約する手法(Schenk，1999)，水平位置 を固定して鉛直方向にのみ座標を変動させ，共線条件 式により空中写真画像上に順次投影する鉛直線軌跡の 手法 (Bethel, 1986), 低解像度にて概略の探索範囲を 決定し高解像度では狭い範囲のみ探索する多重解像度 解析 (Schenk, 1999) 等がある。これらの方法は画像 の探索範囲を制約する手法であり，画像探索範囲を制 約することにより，不要な部分を探索することがなく なり，ミスマッチングの防止を可能としている。

さらに，ステレオモデル間でテンプレートを逐次変 形させ, その類似度が最も高くなるアフィン変換パラ メータを採用する最小二乗マッチングによりサブピク セル単位でのマッチングが達成されている（Foerstner, 1982 ; Ackermann, 1984 ; Gruen, 1985ほか)。 また，テンプレートの変形式に多項式を使用すること によりマッチング精度の向上が確認されているが，そ れでも5\%のミスマッチングが発生しており（Bethmann et al., 2010), ミスマッチング発生の完全な抑 制にはつながっていない。 
ミスマッチングが発生しやすい箇所としては主に以 下の二つが考えられる。一つ目はステレオモデル間の 画像類似度が全体的に低い箇所であり，このような箇 所としてはオクルージョンが発生しやすい山間部など が該当する。一般的なマッチング手法において，ステ レオモデル間の正規化相互相関係数が最大となる地点 もしくは, 画素值の差分が最小となる地点がマッチン グ点の候補となり，画像類似度が全体的に低い箇所の 場合にはマッチング点の候補を採用するか棄却するか の閾值を低く設定することによりマッチングが達成さ れる場合もある。ところが, こうして取得された点の 多くはミスマッチングであり, 結果的にミスマッチン グした点までも採用してしまう危険性が高くなる (Schenk, 1999)。二つ目は画像類似度の極大值が複数 回発生し, 相関係数の最大值が正しいマッチング点で はない場合である (Schenk, 1999)。このような箇所と して, 同様の画像パターンが連続する水田などが該当 する。

これらの原因により発生したミスマッチングを除去 するための手法として以下の手法が提案されている。

Foerstner（1984）は，撮影高度㧍よび周囲の高さ情報 との関係から取得するマッチング点の標高值をあらか じめ推定し, 実際に取得された標高值がそれと大きく かけ離れている場合は除去する手法を提案している。 この手法を用いることにより，地形が平坦な箇所で発 生したミスマッチングについてはある程度除去するこ とが可能であるが, 地形が急峻な個所では正しく取得 したマッチング点を誤って削除する可能性もある。

Zhang ら (2006) は, ステレオモデルの一方の画像か ら他方の画像のマッチング点を検索した後に逆方向の 検索を行い，双方向のマッチング位置を信頼性で評価 するバックマッチング法を提案し，信頼性の低い点を 除去することにより最大 $30 \%$ のスマッチング削減に 成功している。ただし，この手法は画像パターンに繰 り返しがある箇所で発生したミスマッチングについて は検出できない場合も想定される。Zhang ら (2005) は，連続して撮影される多重画像において中心に位置 する画像を基準画像とし, 基準画像と周囲の画像で構 成される複数のステレオモデルのマッチング結果を比 較し，もっとも信頼度の高いステレオモデルを採用す るマルチレイステレオモデル法を提案している。この 手法は, 多視点からの画像情報が利用できるためオク ルージョン箇所や同一パターンの連続箇所に対する
マッチング率の改善に有効な手法であると考えられ る。ただし, この手法は多視点画像から構成される画 像群に対してそれぞれステレオモデルを作成する必要 があるため, 処理時間が増大するという課題がある(武 田ら，2008)。

ところで, 従来の空中写真測量においては進行方向 に対するステレオモデルごとにステレオモデルの形成 が行われていることを考えれば, 進行方向前後のステ レオモデル，さらには隣接コースのステレオモデルの 利用が可能であり，これらの隣接ステレオモデルを利 用することによりステレオモデルを新たに作成する必 要もなくミスマッチング箇所の改善, 防止に関する作 業の効率化, さらには成果である数值標高モデルの高 精度化が達成されるものと考える。

そこで, 本研究では, 隣接するステレオモデルを利 用した逆投影法によるマッチング点の信頼性評価およ びミスマッチングの改善を提案し, 数值標高モデルの 精度向上において本手法の妥当性を検討する。

\section{2. 本研究の原理}

数值標高モデル作成の一般的な処理フローはステレ オモデルを形成してマッチング処理を行うというもの であり，これにエピポーラ画像の作成拉よび多重解像 度解析を用いて, 探索範囲の制約および処理速度の向 上をはかっている。本研究に打ける逆投影法とは, マッ チング処理を行った後, マッチング点を隣接するステ レオモデルに投影し, 投影した地点に扔ける画像の類 似度からマッチング結果の信頼性を評価するものであ る。これにより, 信頼性の低い点が除去され, 写真地 四作成を効率化する上で課題となっているミスマッチ ングが防止されることにより, 数值標高モデルの品質 の維持および向上が行われる。逆投影法を用いた数值 標高モデルの取得処理フローは図1のとおりであり, 処理詳細を次節以降に示す。

\section{1 ステレオモデル組み合わせおよび隣接関係の把握}

本手法では従来の空中写真測量と同様にステレオモ デルをそれぞれ作成するが，図 2 に示すとおり，同一 コースでの隣接関係および隣接コースの関係を把握 し, 処理対象のステレオモデルと評価対象のステレオ モデルの組み合わせを事前に撮影状況から決定し, 処 理対象のステレオモデルがどのステレオモデルを用い 


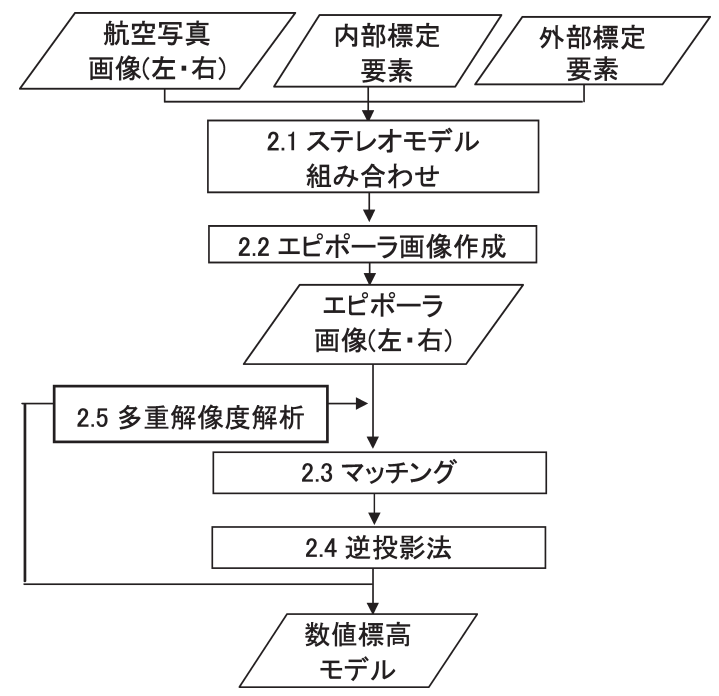

図 1 逆投影法を用いた数値標高モデル取得

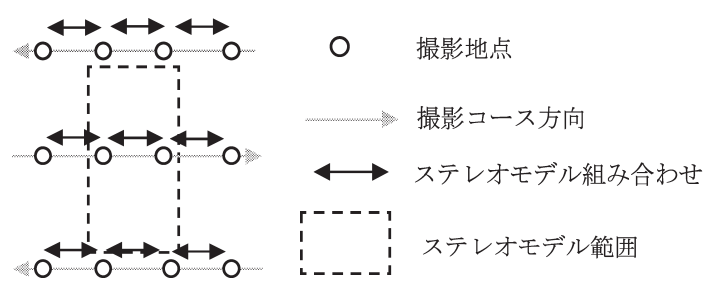

図 2 処理対象ステレオモデルと隣接関係の把握

て評価可能か把握することとする。

\section{2 エピポーラ画像作成}

本研究では各ステレオモデルに対して，エピポーラ 画像を作成する。エピポーラ画像を作成することによ ク，マッチング処理でマッチング点を参照した際の類 似度が向上しマッチングの可否を正しく判定できると いう利点がある。

エピポーラ画像の作成はステレオモデルの左右画像 それぞれについて, 式(1)により基線回転行列 $B$ に回転 行列の転置行列 $R^{T}$ を乗じて偏歪修正行列 $P$ を生成 し, 共線条件式(2)を用いて空中写真画像からエピポー ラ画像に変換する（Schenk，1999）。

$P=B R^{T}=\left|\begin{array}{lll}p_{11} & p_{12} & p_{13} \\ p_{21} & p_{22} & p_{23} \\ p_{31} & p_{32} & p_{33}\end{array}\right|$

$x_{p}=-f_{p} \frac{x_{r^{*}} p_{11}+y_{r^{*}} p_{12}-f_{r^{*}} p_{13}}{x_{r}{ }^{*} p_{31}+y_{r}{ }^{*} p_{32}-f_{r^{*}} p_{33}}$

$y_{p}=-f_{p} \frac{x_{r}^{*} p_{21}+y_{r}^{*} p_{22}-f_{r^{*}} p_{23}}{x_{r}{ }^{*} p_{31}+y_{r}{ }^{*} p_{32}-f_{r}^{*} p_{33}}$
ここで $p_{11} \sim p_{33}$ は偏歪修正行列の各成分， $f_{p}$ は偏歪 修正後の空中写真の画面距離, $f_{r}$ は偏歪修正前の空中 写真の画面距離， $x_{r}, y_{r}$ は偏歪修正前の画像座標， $x_{p}$, $y_{p}$ は偏歪修正後の画像座標である。

\section{3 マッチング}

本研究に打けるマッチング処理手法は写真地図作成 に用いる数值標高モデルが等間隔のメッシュデータで あり，平面座標を定めた上で高さ情報を取得する必要 があることから，鉛直線軌跡の手法を採用することと した。

図 3 に示すとおり, 処理対象のステレオモデル A に 対するマッチング処理により左右のエピポーラ画像上 でマッチング点が取得され, 前方交会法による地上座 標計算式により, 取得したマッチング点の地上座標が 計算される (Schenk, 1999)。すなわち, 空中写真の外 部標定要素の回転要素 $\kappa, \phi, \omega の$ 順に回転した回転行 列の成分 $r l_{11} \sim r l_{33}$ 拈よび $r r_{11} \sim r r_{33}$ を算出し, 左右の エピポーラ画像上で取得したマッチング点の画像座標 $\left(x l_{r}, y l_{r}\right)$ および $\left(x r_{r}, y r_{r}\right)$ を, 共線条件式(3)により偏 歪修正処理前の空中写真画像座標 $\left(u_{1}, v_{1}\right)$ および $\left(u_{2}\right.$, $\left.v_{2}\right)$ 一変換する。ここで $f_{r}$ は偏歪修正前の空中写真の 画面距離である。

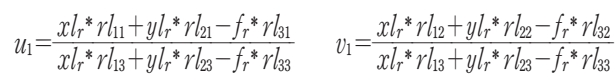
$u_{2}=\frac{x r_{r}^{*} r r_{11}+y r_{r}^{*} r r_{21}-f_{r}^{*} r r_{31}}{x r_{r}^{*} r r_{13}+y r_{r}^{*} r r_{23}-f_{r}^{*} r r_{33}} \quad v_{2}=\frac{x r_{r}^{*} r r_{12}+y r_{r}{ }^{*} r r_{22}-f_{r}^{*} r r_{32}}{x r_{r}^{*} r r_{13}+y r_{r}{ }^{*} r r_{23}-f_{r}^{*} r r_{33}}$

さらに，式(4)によりステレオモデル A における交会 残差を最小とするマッチング点の高さ情報 $Z_{r}$ を計算 し，式(5)によりその值を代入して左右写真上に扔ける マッチング点の地上座標 $L X_{r}, L Y_{r}$ 扩よび $R X_{r}, R Y_{r}$ を得て, 式(6)によるマッチング点の三次元座標 $G_{x}, G_{y}$ を算出する。式(5)における $L X_{c}, L Y_{c}, L Z_{c}$ 抒よび $R X_{c}, R Y_{c}, R Z_{c}$ は空中写真の撮影地点座標である。

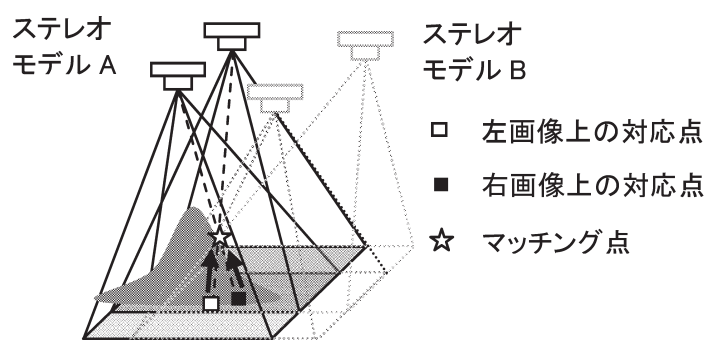

図 3 処理対象におけるマッチング点の概念図 
$k_{1}=L X_{c}-u_{1}^{*} L Z_{c} \quad k_{2}=L Y_{c}-v_{1}^{*} L Z_{c}$

$k_{3}=R X_{c}-u_{2}{ }^{*} L Z_{c} \quad k_{4}=R Y_{c}-v_{2}^{*} L Z_{c}$

$Z_{r}=-\frac{\left(u_{2}-u_{1}\right) *\left(k_{3}-k_{1}\right)+\left(v_{2}-v_{1}\right) *\left(k_{4}-k_{2}\right)}{\left(u_{2}-u_{1}\right) *\left(u_{2}-u_{1}\right)+\left(v_{2}-v_{1}\right) *\left(v_{2}-v_{1}\right)}$

$L X_{r}=\left(Z_{r}-L Z_{c}\right) * u_{1}+L X_{c} \quad L Y_{r}=\left(Z_{r}-L Z_{c}\right) * v_{1}+L Y_{c}$

$R X_{r}=\left(Z_{r}-R Z_{c}\right) * u_{2}+R X_{c} \quad R Y_{r}=\left(Z_{r}-R Z_{c}\right) * v_{2}+R Y_{c}$

$G_{x}=\left(L X_{r}+R X_{r}\right) / 2$

$G_{y}=\left(L Y_{r}+R Y_{r}\right) / 2$

\section{4 逆投影法}

本研究で提案する逆投影法は, 取得したマッチング 点の三次元座標を隣接する評価対象のステレオモデル に投影し，投影したステレオモデル上で類似度を算出 してマッチング点の信頼性を評価するものである。

2.2節によって既に隣接するステレオモデルに対し てもあらかじめエピポーラ画像が作成されていること から，正しくマッチングした点は投影した評価対象の ステレオモデルにおいて類似度が高く評価されること となる。なお, 逆投影法は, 従来法と同様にステレオ モデルを構築しているため, 改めて評価用にステレオ モデルを作成する必要がないため，処理コストを最小 限に抑えられるという利点を持つ。

式(6)によって算出された三次元座標は共線条件式に よるバックプロジェクションの式 (Schenk, 1999) を 用いて隣接する評価対象のステレオモデル B に投影 計算される(図 4 )。

投影計算は，まず空中写真の外部標定要素を元に隣 接するステレオモデル B の左右空中写真を $\kappa, \phi, \omega$ の 順に回転した回転行列を作成し, 共線条件式を用いて, 取得したマッチング点の地上座標を隣接するステレオ モデル B の偏歪修正処理前の左右空中写真上に投影 する。次にステレオモデル B の左右空中写真の外部標

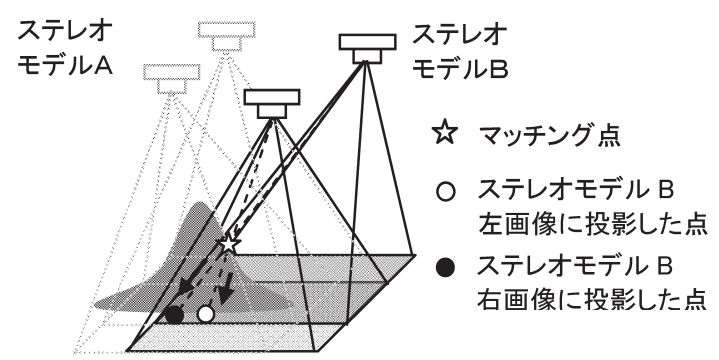

図 4 評価対象における逆投影の概念
定要素を地上座標系から, 左空中写真の撮影地点を原 点とし左右空中写真の基線方向を X 軸とする右手座 標系とするモデル座標系に変換し, モデル座標系に変 換した外部標定要素の回転要素 $\kappa, \phi, \omega の$ 順に回転し た基線回転行列を得る。最後にステレオモデル B の左 右画像それぞれについて偏歪修正行列を生成し, 空中 写真画像座標からエピポーラ画像座標に変換する。

マッチング点の信頼性は, 評価対象の隣接するステ レオモデルのエピポーラ画像上に投影した地点に対し て, 周囲の画像パターンの類似度を比較することによ り評価する。類似度が高い場合は取得したマッチング 点を採用し, 低い場合はマッチング処理の結果を棄却 する。なお, 本研究では類似度の指標として画像の色 調・コントラストによる影響を受けにくい正規化相互 相関係数を用いることとした。

ここで，投影計算における処理時間は，逆投影する ステレオモデル数に依存することが想定されるから， 本研究では逆投影するステレオモデルの組み合わせ方 法を考慮し，全モデルおよび同一コースのステレオモ デル, 隣接コースのステレオモデルに対し, マッチン グの信頼性と処理時間から最適な組み合わせについて 検証を実施した。

なお，1つのマッチング点に対して投影可能なステ レオモデルが複数存在する場合は, 次の手順でマッチ ング点の信頼性を判定する。

・隣接するステレオモデルにマッチング点を投影し, それぞれのステレオモデル上での類似度を計算す る。

・各ステレオモデルについて類似度が指定した閾值以 上の場合は一票を投票する。

・得票数が隣接するステレオモデル数の半数以上の場 合にはマッチング点を採用とし, 半数未満の場合は 棄却する。

ここで用いる類似度の閾值は, 画像の色調・コント ラストによる影響を受けにくい正規化相互相関係数を 評価指標として用いていることから，一意な閾值を設 定することが可能であると考え，一般的にかなり強い 相関があるとされている0.4（前野·三国，2000）を使 用することとした。

また, 得票数の閾值を評価可能なステレオモデル数 の半数に設定した理由は, 全数に設定すると正しく取 得されているマッチング点について樹木による隠蔽な どが起こっている場合に棄却される場合があること， 
表 1 撮影諸元

\begin{tabular}{|c|c|c|c|c|c|c|c|c|c|c|c|}
\hline \multirow[b]{2}{*}{ 地区 } & \multirow[b]{2}{*}{ 地物の種別 } & \multirow[b]{2}{*}{ カメラ } & \multirow{2}{*}{$\begin{array}{c}\text { 焦点距離 } \\
(\mathrm{mm})\end{array}$} & \multirow{2}{*}{$\begin{array}{l}\text { 画素 } \\
\text { サイズ } \\
\text { (um) }\end{array}$} & \multirow[b]{2}{*}{ 撮影縮尺 } & \multirow{2}{*}{$\begin{array}{l}\mathrm{OL} \\
(\%)\end{array}$} & \multirow{2}{*}{$\begin{array}{l}\mathrm{SL} \\
(\%)\end{array}$} & \multirow{2}{*}{$\begin{array}{l}\text { 対地 } \\
\text { 高度 } \\
(\mathrm{m})\end{array}$} & \multirow{2}{*}{$\begin{array}{c}\text { 基線 } \\
\text { 長 } \\
(\mathrm{m})\end{array}$} & \multicolumn{2}{|c|}{ 理論值 } \\
\hline & & & & & & & & & & $\begin{array}{l}\text { 平面 } \\
(\mathrm{m})\end{array}$ & $\begin{array}{l}\text { 高さ } \\
(\mathrm{m})\end{array}$ \\
\hline A & 山地 & $\mathrm{DMC}$ & 120.00 & 12 & $1: 16,000$ & 60 & 50 & 1944 & 561 & 0.194 & 0.953 \\
\hline B & 山地·田畑 & $\mathrm{RC} 30$ & 153.32 & 20 & $1: 15,000$ & 60 & 50 & 2126 & 1115 & 0.277 & 0.748 \\
\hline $\mathrm{C}$ & 山地·田畑 & RC30 & 152.94 & 20 & $1: 12,000$ & 70 & 50 & 2089 & 740 & 0.273 & 1.090 \\
\hline $\mathrm{D}$ & 山地 - 住宅地 & DMC & 120.00 & 12 & $1: 16,000$ & 60 & 30 & 2074 & 593 & 0.207 & 1.025 \\
\hline $\mathrm{E}$ & 山地·住宅地 & $\mathrm{RC} 30$ & 213.90 & 20 & $1: 12,500$ & 60 & 30 & 2709 & 1123 & 0.253 & 0.864 \\
\hline
\end{tabular}

逆に限りなく 0 に近い值に設定すると水田箇所など同 様のパターンが連続する場合には䛊って取得したマッ チング点を採用する危険性を考慮したものである。

マッチングが裹却された場合には，すべてのマッチ ング点に対して逆投影法による評価が終了した後, 棄 却された点の周囲の採用されたマッチング点を用いて 標高值を内抻して次の処理ステップに進むこととし た。

\section{5 多重解像度解析}

多重画像解析は, 原画像と同一の解像度を有する工 ピポーラ画像から段階的に解像度を下げた画像を作成 し, 最低解像度の画像から順にマッチング点を検索す る手法であり，これによりマッチング点の検索範囲が 絞り込まれ，マッチング処理が高速化される。しかし， 処理途中でミスマッチングが発生した場合は, 最後ま でマッチング点を修正することができないため，処理 の途中でミスマッチングを除去して補正を行う必要が ある。Foerstner (1984) は取得したマッチング点の高 さ情報が周囲と大きく異なる場合は除去することによ り補正を行っているが, この手法では地形が急峻な箇 所では正しく取得したマッチング点まで削除してしま う可能性がある。そこで, 本研究で提案する逆投影法 では, 多重解像度解析の各ステップにおいて, 取得し たマッチング点の信頼性を評価し，信頼性の低いマッ チング点を除去することにより，ミスマッチングを正 しく除去できるものとした。

\section{3. 実験結果および考察}

本研究で提案する逆投影法の有効性を実際の空中写 真を使用して実験を行った。逆投影法の評価は，撮影
された空中写真から作成した数值標高モデルを用いて 定性的・定量的な評価を行った。

\section{1 計測諸元}

本研究に使用する空中写真画像デー夕は，ミスマッ チングの発生頻度の高い山地を含む地域を対象とし て, アナログ航空カメラまたはデジ夕ル航空カメラに よって撮影されたそれぞれ撮影諸元の異なるものを使 用した。検証データの計測諸元を表 1 に示す。なお, アナログ航空カメラについては表 1 に示す画素サイズ によって数值化した。

\section{2 逆投影法による効果の確認}

本節ではマッチング処理における逆投影法の効果を 確認し，それによって従来のミスマッチ判定手法にお ける課題が解決されることを確認する。

\subsection{1 エピポーラ画像作成}

エピポーラ画像作成の効果を実際の画像を使用して 確認を行った。図 5 に偏歪修正処理前の空中写真画像 とエピポーラ画像でマッチングした地点の類似度を示

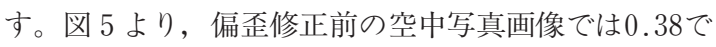
あるが, エピポーラ画像では 0.60 と類似度の向上が見 られ, エピポーラ画像作成の効果が改めて確認された。

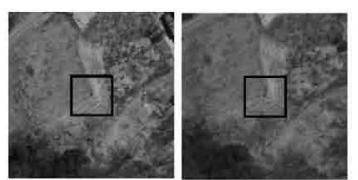

偏歪修正前の空中写真画像 正規化相互相関係数: 0.38

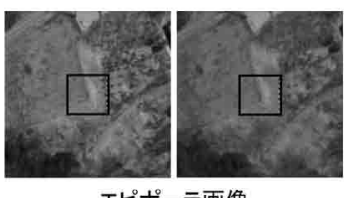

エピポーラ画像 正規化相互相関係数: 0.60
図 5 偏歪修正前の空中写真画像とエピポーラ画像におけ るマッチング 


\subsection{2 逆投影法}

ここでは, マッチング処理後に逆投影法を行うこと によって，マッチング箇所またはミスマッチング箇所 が正しく判定されることを確認し, 既往の手法である Foerstner (1984) の手法，バックマッチング法 (Zhang et $a l .$, 2005) およびマルチレイステレオモデル法 (Zhang et al., 2006) と比較し, その有効性について 確認する。

(1) マッチング箇所における逆投影

まず，マッチング処理により正しく取得されたマッ チング点が，逆投影法により正しく判定されるかにつ いて確認を行ったところ, 図 6 のとおりマッチング処 理を行ったステレオモデル A での類似度が 0.48 , 隣接 するステレオモデル B での類似度が 0.66 といずれも 閾值を超過してマッチング点と判定されていることが 確認された。

(2) 急傾斜箇所における逆投影

続いて，急峻な山地で正しく取得されたマッチング 点が，逆投影法により正しく判定されるかについて確
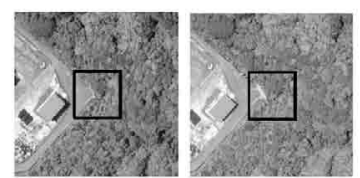

(a) ステレオモデル A 正規化相互相関係数: 0.48

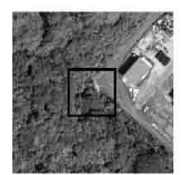

(b) ステレオモデル B 正規化相互相関係数: 0.66
図 6 マッチング処理および逆投影によるパターン比較 国土地理院撮影の空中写真（2008年撮影）を使用

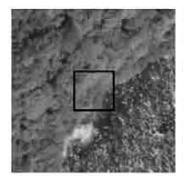

(a) ステレオモデル A 正規化相互相関係数: 0.42

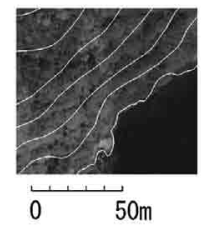

写真地図および

図化等高線図 (等高線間隔は $10 \mathrm{~m}$ )

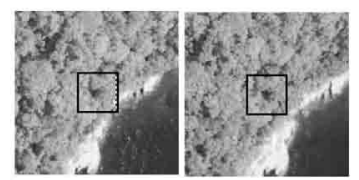

(b) ステレオモデル B 正規化相互相関係数: 0.68

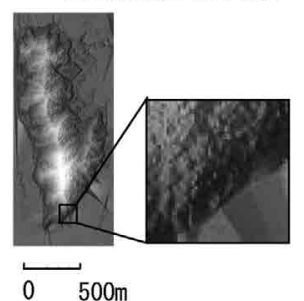

図 7 マッチング処理および逆投影によるパターン比較 （急傾斜箇所・地区Ａ）および逆投影法を用いて作成 した数值標高モデル

国土地理院撮影の空中写真（2008年撮影）を使用
認を行った。これは，撮影高度および周囲のマッチン グ点の高さ情報との関係から信頼性を評価する Foerstnerの手法を用いた場合，このような箇所は隣接す るマッチング点の高さ情報との差が大きいことから， 正しく取得したマッチング点を誤って䢂却してしまう 可能性があり，その課題が解決されているかを確認す るものである。

図 7 は隣接するマッチング点の高さ情報との差が数 十メートルある急傾斜箇所で取得されたマッチング点 であり，逆投影法によりステレオモデル $\mathrm{A}$ の類似度が 0.42 , ステレオモデル B の類似度が 0.68 となりマッチ ング点と判定された。

このように, 画像の類似度によって評価する逆投影 法は，隣接するマッチング点の高さ情報に依存するこ となく, 取得したマッチング点を正しく評価すること が可能である。

(3) 水田箇所における逆投影

次に, 同様な画像パターンが連続する水田箇所で発 生したミスマッチングが，逆投影法により竦却される かについて確認を行った。これは, ステレオモデル双 方向からマッチング点の信頼性を評価するバックマッ チング法を用いた場合，このように同様な画像パター ンが連続する箇所においてはミスマッチングを検出す ることが困難な場合があり, その課題が解決されてい るかを確認するものである。

困 8 (a)はステレオモデル A 上でエピポーラライン と平行な方向に同様の画像パターンが連続する畦道で 発生したミスマッチングである。図 8 (b)は逆投影法に よりこのマッチング点を隣接するステレオモデル B に投影した像であるが，ステレオモデル B における類

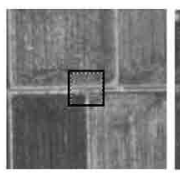

(a) ステレオモデル A 正規化相互相関係数 : 0.51

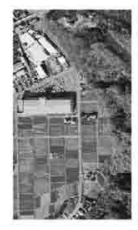

2 $200 \mathrm{~m}$

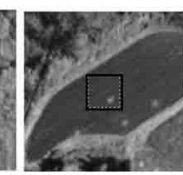

(b) ステレオモデル B 正規化相互相関係数 : -0.08
図 8 マッチング処理および逆投影によるパターン比較 （水田箇所・地区 B）および同箇所の数值標高モデル 
似度がー 0.08 と低くなり，ミスマッチングとして検出 された。

このように，逆投影法は同様の画像パターンが連続 する場所についても，ミスマッチングとして検出する ことが可能である。

(4) 逆投影法による処理時間

マルチレイステレオモデル法は，連続して撮影され る多重画像において中心に位置する画像を基準画像と し, 基準画像と周囲の画像で構成される複数のステレ オモデルのマッチング結果を比較し，もっとも信頼度 の高いステレオモデルを採用する手法であるが，多視 点画像から構成される画像群に対してそれぞれステレ オモデルを作成するため, 処理時間について課題が残 る方法である。

いっぽう，逆投影法では，すでに形成されているス テレオモデルをそのまま使用することが可能であるた め, 新たにステレオモデルを形成するための処理時間 が発生することはない。

\subsection{3 多重解像度解析}

多重解像度解析の各段階で計算された数值標高モデ ルから，標高值を任意の段階に区分し，各段階を異な る色で表現する段彩図を作成することにより，ミス マッチングが多重解像度解析の各段階で除去されてい ることを確認する。

図 9 に多重解像度解析の各段階で計算された数值標 高モデルから作成した段彩図を示す。逆投影法を使用
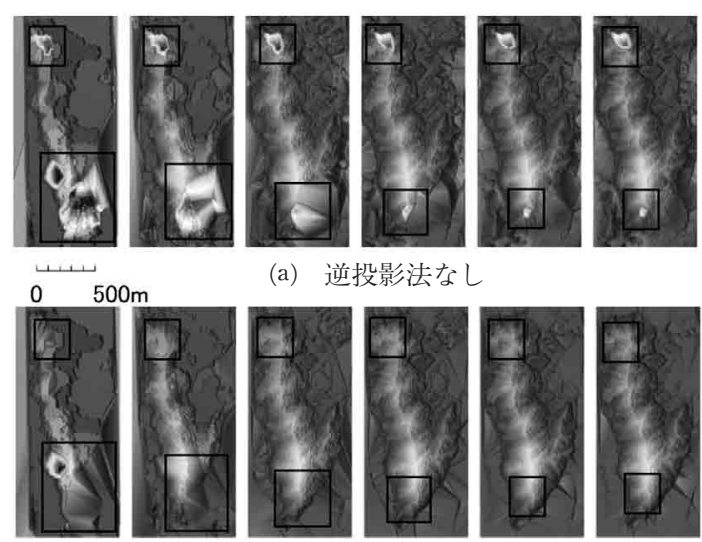

(a)
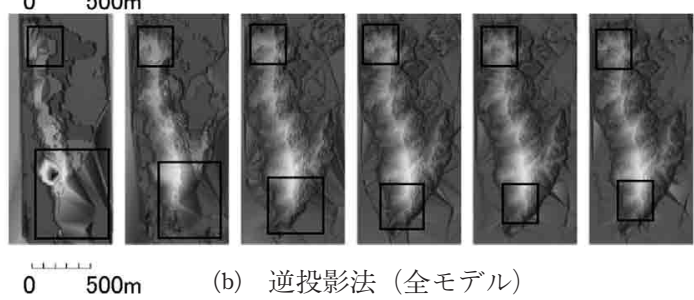

（b）逆投影法（全モデル）

\section{世低解像度}

高解像度 $\rightarrow$

図 9 多重解像度解析における数值標高モデルの推移（地 区 A)

国土地理院撮影の空中写真（2008年撮影）を使用
しない場合では，低解像度の段階で発生したミスマッ チングが高解像度においても改善されていないが，逆 投影法を用いることにより低解像度の段階で発生した ミスマッチングが高解像度に至る過程で解消されてい ることが確認できる。なお，段彩困は格子間隔 $2 \mathrm{~m}$ で 作成した数值標高モデルを, 高さ情報の最小值と最大 值の間を20,000階調として表現したものである。

\section{3 精度検証}

本節では，逆投影法による効果および，逆投影法の ケース別の改善効果を確認するために，マッチング処 理により数值標高モデルを作成して定量的・定性的な 評価を行う。

\subsection{1 定量的な評価}

ミスマッチング発生頻度の高い山地を含む地域を対 象として, 最確值にレーザデータを用いて定量的な精 度検証を行う。また，逆投影法を行うステレオモデル の組み合わせについて, 全モデルおよび同一コースの ステレオモデル，隣接するステレオモデルを用いた場 合の結果についても評価する。

レーザデータを用いた検証は，レーザデータの信頼 性の高い平坦な地形から検証点を選定し, レーザデー 夕に対する標高值の平均二乗誤差およびミスマッチン グの数による検証を行った。なおここでのミスマッ チングは式(7)に示す視差方程式から導かれる理論值 $\sigma_{Z 0}$ を超えるものとした。

$\sigma_{X Y 0}=\frac{H}{f} \sigma_{p}, \quad \sigma_{Z 0}=\sqrt{2} \frac{H}{f} \frac{H}{B} \sigma_{p}$

$\sigma_{X Y 0}$ : 平面座標の理論值, $\sigma_{Z 0}$ : 高さ座標の理論值,

$H$ : 対地高度, $f$ : 焦点距離, $B$ : 基線長, $\sigma_{p}$ : 読取誤 差（本研究では 1 画素とする。）

ここで用いる検証点の平面座標は, マッチング点の 平面座標を使用することとし，レーザデータに同一の 平面座標が存在しない場合には, レーザデータから不 等辺三角網を生成し, 内挿処理によって標高值を算出 して比較することとした。なお，本研究の最確值とす るレーザデータは, 計測密度 2.8 点 $/ \mathrm{m}^{2}$, 地困情報レベ ル2500の精度を満たすものである。

表 2 に標高值較差の平均二乗誤差を, 表 3 にミス マッチングの発生数を示す。なおここで言うミスマッ チングとは, 各検証点についてマッチング点とレーザ 


\section{表 2 平均二乗誤差}

\begin{tabular}{|r|r|r|r|r|c|}
\hline $\begin{array}{r}\text { 地 } \\
\text { 区 }\end{array}$ & $\begin{array}{r}\text { 検証 } \\
\text { 点数 }\end{array}$ & $\begin{array}{c}\text { 逆投影 } \\
\text { 法なし } \\
(\mathrm{m})\end{array}$ & $\begin{array}{c}\text { 全モデル } \\
(\mathrm{m})\end{array}$ & $\begin{array}{c}\text { 同一 } \\
\text { コース } \\
(\mathrm{m})\end{array}$ & $\begin{array}{c}\text { 隣接 } \\
\text { コース } \\
(\mathrm{m})\end{array}$ \\
\hline $\mathrm{A}$ & 126 & 0.913 & 0.862 & 0.833 & 0.823 \\
\hline $\mathrm{B}$ & 290 & 0.986 & 0.769 & 0.937 & 0.722 \\
\hline $\mathrm{C}$ & 1049 & 0.877 & 0.739 & 0.836 & 0.799 \\
\hline $\mathrm{D}$ & 730 & 0.752 & 0.646 & 0.736 & 0.698 \\
\hline $\mathrm{E}$ & 1161 & 0.711 & 0.643 & 0.664 & 0.616 \\
\hline
\end{tabular}

表 3 ミスマッチング箇所数

\begin{tabular}{|c|r|r|r|r|r|}
\hline $\begin{array}{c}\text { 地 } \\
\text { 区 }\end{array}$ & $\begin{array}{c}\text { 検証 } \\
\text { 点数 }\end{array}$ & $\begin{array}{c}\text { 逆投影 } \\
\text { 法なし }\end{array}$ & 全モデル & $\begin{array}{c}\text { 同一 } \\
\text { コース }\end{array}$ & $\begin{array}{c}\text { 隣接 } \\
\text { コース }\end{array}$ \\
\hline $\mathrm{A}$ & 126 & 15 & 13 & 14 & 14 \\
\hline $\mathrm{B}$ & 290 & 106 & 89 & 97 & 89 \\
\hline $\mathrm{C}$ & 1049 & 185 & 132 & 168 & 165 \\
\hline $\mathrm{D}$ & 730 & 153 & 122 & 149 & 126 \\
\hline $\mathrm{E}$ & 1161 & 263 & 239 & 253 & 232 \\
\hline
\end{tabular}

データの Z 座標值の較差絶対值が, 高さ座標の理論值 を超過したものとした。

表 2 , 表 3 より，逆投影法を用いることにより平均 二乗䛊差およびミスマッチングの発生数ともに，逆投 影法を用いなかった場合と比較して改善されているこ とが確認できる。また，逆投影法を用いることにより， 樹木による隱蔽部などにおいて一部マッチング点がミ スマッチングに転ずる場合も見られたが，全体的には 改善傾向にあることが確認できる。

さらに，逆投影するステレオモデルは，全モデルを 使用した場合および隣接コースを使用した場合に良い 結果が得られる傾向にあり，同一コースのステレオモ デルを使用した場合は，他の投影方法と比較してミス マッチング数が多いことも確認できる。

\section{3 .2 定性的な評価}

マッチング処理によって作成した数值標高モデルを 用いて段彩図を作成し, 標高の変化を視覚的に把握し， 広範囲を定性的に評価することにより，逆投影法の効 果を確認する。

図10にマッチング範囲全体を示す写真地図および段 彩図を示す。図中の四角で示したとおり全モデルおよ び隣接コースのステレオモデルに対して逆投影法を用 いることにより，山地箇所・水田箇所で発生したミス

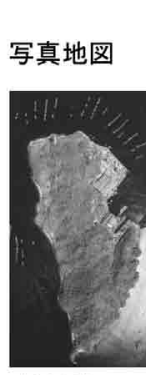

$0 \quad 500 \mathrm{~m}$ 逆投影法 なし
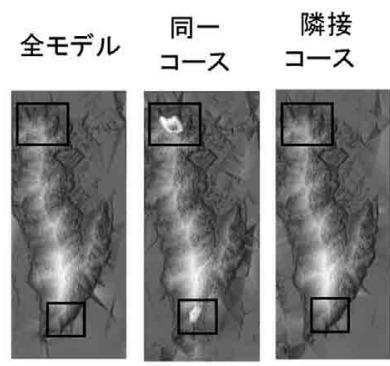

(a) 山地部 (地区 A)

国土地理院撮影の空中写真 (2008 年撮影)を使用

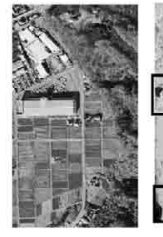

$0200 \mathrm{~m}$

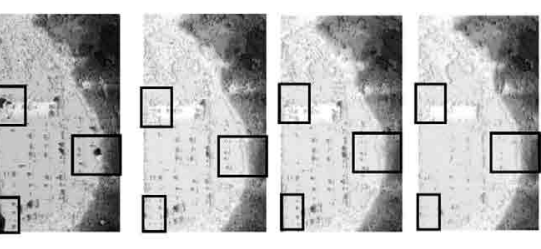

（b）水田部（地区 $\mathrm{B}$ )
図10 逆投影法により取得した数值標高モデル

マッチングが改善されていることが確認される。段彩 困は前節と同様の手法により作成した。

\section{4 考 察}

逆投影法を行うステレオモデルの組み合わせについ て，全モデルおよび同一コースのステレオモデル，隣 接するステレオモデルを用いた場合の結果の差異につ いて考察を行う。

3.3節のとおり，レーザデータとの比較掞よび段彩図 による評価により, 同一コースのステレオモデルを使 用した場合よりも全コースおよび隣接コースのステレ オモデルを使用した場合について良好な結果を得られ ることが確認された。これは逆投影法に使用するステ レオモデルの違いにより逆投影可能な範囲が変化する ことに起因しているものと考えられる。なぜならば, 逆投影法はその仕組み上, 取得したマッチング点を投 影するステレオモデルが存在しない場合にマッチング 点の信頼性を評価できないため, マッチング点の信頼 性の評価は, 逆投影可能な領域の割合に依存するから である。

表 4 は, 公共測量において標準的に用いられるオー バーラップ率 $60 \%$ ， サイドラップ率 $30 \%$ で撮影された 地区 D について, 逆投影可能な領域の占める割合とミ スマッチング筒所の削減数を示したものである。逆投 影可能な領域の占める割合は全モデルを使用した場合 が最も高く, 同一コースのモデルを使用した場合が最 
表 4 逆投影可能な領域の占める割合とミスマッチング箇 所の削減数（地区 D)

\begin{tabular}{|c|c|c|c|c|c|}
\hline & \multirow{2}{*}{$\begin{array}{l}\text { 逆投影可 } \\
\text { 能な領域の } \\
\text { 占める割合 } \\
(\%)\end{array}$} & \multicolumn{2}{|c|}{$\begin{array}{l}\text { 逆投影可能な領域内 } \\
\text { ミスマッチング箇所数 }\end{array}$} & \multirow{2}{*}{ 削減数 } & \multirow{2}{*}{$\begin{array}{c}\text { 削減率 } \\
\text { (逆投影 } \\
\text { 可能な領 } \\
\text { 域内) }\end{array}$} \\
\hline & & $\begin{array}{l}\text { 逆投影 } \\
\text { なし }\end{array}$ & $\begin{array}{l}\text { 逆投影 } \\
\text { あり }\end{array}$ & & \\
\hline 全モデル & 78.0 & 121 & 90 & 31 & $25.6 \%$ \\
\hline 同一コース & 43.0 & 38 & 34 & 4 & $11.8 \%$ \\
\hline 隣接コース & 58.2 & 105 & 78 & 27 & $25.7 \%$ \\
\hline
\end{tabular}

も低いことが確認される。また，ミスマッチング箇所 数は, 全モデルを使用した場合が最も多く, 同一コー スのモデルを使用した場合が最も少ないことが確認で きる。同様に，逆投影可能な領域に含まれるミスマッ チング箇所数が多いほど削減されるミスマッチング箇 所数も多いことから，逆投影可能な領域と削減数は比 例関係にあると推察される。

以上のとおり，ミスマッチング箇所の削減数は，隣 接する全モデルに逆投影した場合において最も高い効 果が確認できるが，削減率では隣接コースに逆投影し た場合と僅差であること, さらに逆投影処理にかかる 時間を考慮すると，隣接コースに逆投影することが有 効であると考えられる。

また，逆投影可能な領域内におけるミスマッチング 削減率は，全モデルおよび隣接コースと比較して同一 コースの削減率が低くなっている。これは図10に示し たようなミスマッチング箇所について，同一コースの ステレオモデルに逆投影する場合，エピポーラライン の方向がほぼ同一となるため, ステレオモデル A上で の写像とほぼ同様になりミスマッチングとして検出で きないことによると推測される。

なお，逆投影可能な範囲内にも関わらず結果が改善 しなかった箇所が存在したが，その多くは樹木による 隠蔽箇所であり，従来手法と同様に高い信頼度を持つ マッチングを行うことが困難な箇所であった。

\section{4.まとめ}

本研究では数值標高モデルの精度向上を目的とし て，マッチング処理において発生するミスマッチング 箇所を除去する逆投影法について提案し, 撮影条件が 異なる 5 種類のデータを使用して評価を行った。その 結果, レーザデータとの比較による評価および段彩図 を使用した評価において, 逆投影法の効果が確認でき,
特に隣接する全ステレオモデルおよび隣接コースのス テレオモデルを使用した逆投影法が有効であることが 理解された。

また, 従来手法においては竦却されていた急傾斜筒 所についても正しくマッチングの評価が行われている こと，水田箇所など同一のパターンが連続する箇所で 発生したミスマッチングについても正しく除去されて いることが確認された。

本手法は多重解像度化法における, 低解像度での マッチング処理の際に発生したミスマッチングが高解 像度まで残ってしまうという課題についても, 各解像 度で発生したミスマッチングを正しく除去することに より解決した。これにより, 多重解像度化法の利点で ある高速な処理を活かした上で，マッチング処理の信 頼性を向上させることに成功した。

いっぽう, 多視点画像を用いたマッチング処理の課 題であった処理時間の増大に関しては，新たにステレ オモデルを形成することなく, 従来の空中写真測量業 務において取得される進行方向前後のステレオモデル および隣接するコースのステレオモデルを用いること により，処理時間の増大を招くことなく上記の結果を 得ることに成功した。

特に, 本研究は通常の空中写真測量業務において取 得される隣接コースのステレオモデルを利用すること に特徵があるため, 数值標高モデルの精度向上, 取得 間隔の高密度化, 計測範囲の広域化等を対象とした今 後の空間データ整備の効率化に寄与するものと期待さ れる。

(受付日2011.1.5，受理日2011.3.11）

\section{参考文献}

1. Schenk, T., 1999. Digital Photogrammetry, Volume I : Background, Fundamentals, Automatic Orientation Procedures, TerraScience, pp231-266, pp301-313.

2 . Bethel, J., 1986. The DSR11 image correlator, In Proc. ACSM/ASPRS Ann. Covention, 4, 44-49.

3 . Foerstner, W., 1982. On the geometric precision of digital correlation. Int. Archives of Photogrammetry vol. 24 III, Proceedings of the Symposium of the ISPRS Commision III Helsinki : 176-189.

4. Ackermann, F., 1984. Digital Image Corrlation : Performance and Potential in Photogrammetry. 
Photogrammetric Record 11(64), S. 429-439.

5. Gruen A.W., 1985. Adaptive Least-Squares Corrlation: A Powerful Image Matching Technique, South African Journal of Photogrammetry, Remote Sensing and Cartography, 14(3) : S. 175187.

6. Bethmann, F., Luhmann T., 2010. LeastSquares Matching With Advanced Geometric Transformation Models, IAPRS and SIS, 38, Part5 Cpmmission V Symposium, Newcastle upon Tyne, UK.

7. Foerstner W., 1984. Quality Assessment of Object Location And Point Transfer Using Digital Image Correlation Techniques, IBID., 25(3a), 197-219.
8. Zhang, B., Miller, S., DeVenecia, K., Walker, S., 2006. Automatic terrain extraction using multiple image pair and back matching, ASPRS 2006 Annual Conference. Reno, Nevada. May 1-5.

9. Zhang, J., Zhang, Y., Zhang, Z., 2005. MultiImage Matching for Generation of DSM and True Ortho-Image. MIPPR 2005: SAR and Multispectral Image Processing. Proc. Of SPIE Vol. 6043 60431R, pp.1-7.

10．武田浩志，赤松幸生，南 義彦，2008．独立偏位 修正法による多重撮影画像の特徵探索，写真測量と リモートセンシング, Vol. 47, No. 2, pp.16-25.

11. 眓解でわかる統計解析：前野昌弘・三國 彰, 日 本実業出版社，2000，pp.227. 